\title{
Not Fused
}

National Cancer Institute

\section{Source}

National Cancer Institute. Not Fused. NCI Thesaurus. Code C124566.

Not joined to form a single entity. 